\title{
Acute appendicitis in pregnancy
}

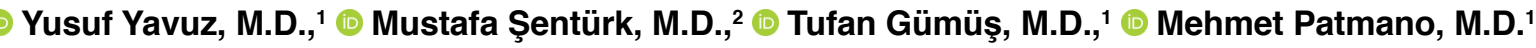

\author{
${ }^{1}$ Department of General Surgery, Şanlıurfa Training and Research Hospital, Şanlıurfa-Turkey \\ ${ }^{2}$ Department of General Surgery, Necmettin Erbakan University Meram Faculty of Medicine, Konya-Turkey
}

\begin{abstract}
BACKGROUND: Acute appendicitis is the most common cause of non-obstetric acute abdomen in pregnant women. We examined the patients who were admitted to our emergency department with abdominal pain and diagnosed with acute appendicitis in the light of the literature.
\end{abstract}

METHODS: Seventeen pregnant patients with acute appendicitis who were admitted to the emergency department of Sanliurfa Training and Research Hospital between the years of 2016-2019 were retrospectively analyzed using an electronic recording system. Our patients were evaluated concerning age, gestational week, clinical status, the operation performed, ultrasonography results, pathology results, presence of additional diseases, laboratory results and hospital stay length.

RESULTS: The mean age of our patients was 25.5 (I8-4I) years. Three patients were in the first trimester (I7.6\%), II patients were in the second trimester $(64.8 \%)$, and three patients were in the third trimester (17.6\%) at the time of admission. All of our patients had abdominal pain. Acute appendicitis was detected in II patients, while it was not detected in six patients on the USG examination. Two patients having term delivery underwent caesarean section with concurrent appendectomy. The mean hospital stay length was 2.9 (2-5) days. Histopathologically, $13(86.7 \%)$ of our operated patients were diagnosed with appendicitis. No additional problems were observed in the mothers and infants in the postoperative period.

CONCLUSION: Acute appendicitis should be considered as a non-obstetric pathology in pregnant patients admitted to the emergency department with abdominal pain. We think that it is important for both maternal and infant health to examine this condition, which shows differences concerning clinical course and physical examination, with a meticulous and multidisciplinary approach.

Keywords: Acute appendicitis; pregnancy; treatment.

\section{INTRODUCTION}

Acute appendicitis is the most common pathology that causes non-obstetric acute abdomen during pregnancy. The incidence of acute appendicitis, which causes acute abdomen with the same frequency in pregnant and non-pregnant women, is between $1 / / 250$ and $1 / 2000 .^{[1,2]}$ Unlike non-pregnant women, pregnant women with acute appendicitis were usually admitted to obstetrics and gynecology clinics, and pregnancy-related causes are considered first. Changes in anamnesis and physical examination depending on the size of the fetus and the difference in hormonal balance make the diagnosis difficult or late. Also, the inability to perform tomography imaging due to ionizing radiation and the lack of a specific laboratory test lead to delays in diagnosis. This situation is important concerning maternal and fetal mortality and morbidity. ${ }^{[3,4]}$ Ultrasonography is the most common radiological method used in the diagnosis of acute appendicitis in pregnant women. ${ }^{[5]}$ Although appendicitis is encountered in every trimester during pregnancy, its incidence is slightly higher in the second trimester compared to others. ${ }^{[6-I I]}$ Acute appendicitis cases in the third trimester are confused with labor and do not always provide positive results for physical examination. The management of surgical and anesthesia processes gain importance concerning maternal and fetal morbidity and mortality in pregnant appendicitis patients, who should be evaluated with a multidisciplinary approach concerning general surgery and gynecology. ${ }^{[12,13]}$

Cite this article as: Yavuz Y, Şentürk M, Gümüş T, Patmano M. Acute appendicitis in pregnancy. Ulus Travma Acil Cerrahi Derg 2021;27:85-88.

Address for correspondence: Mustafa Şentürk, M.D.

Necmettin Erbakan Üniversitesi Meram Tıp Fakültesi, Genel Cerrahi Anabilim Dalı, Konya, Turkey

Tel: +90 332 - 2234055 E-mail: m-sntrk@hotmail.com

Ulus Travma Acil Cerrahi Derg 2021;27(1):85-88 DOI: 10.14744/tjtes.2020.22792 Submitted: 28.12.2019 Accepted: 26.03.2020 Online: 09.12.2020

Copyright 2021 Turkish Association of Trauma and Emergency Surgery 
In this study, we aimed to retrospectively evaluate the follow-up and treatment of pregnant patients diagnosed with acute appendicitis during the hospital stay in light of the literature.

\section{MATERIALS AND METHODS}

The data of 17 pregnant patients who were treated in our clinic with the diagnosis of acute appendicitis between the years of 2016-2019 were examined retrospectively. Ethics committee approval was not received for this study because of retrospective design. Age, gestational week, additional disease findings, admission complaints, physical examination findings, laboratory findings, preoperative ultrasonography reports, anesthesia reports, hospital stay length and pathology reports of the patients were evaluated. All of our patients were consulted to the obstetrics and gynecology clinic, fetal heart rate and viability of the fetus were monitored by ultrasonography in preoperative and postoperative periods. This research was conducted following the principles of "The World Medical Association Declaration of Helsinki: Ethical Principles for Medical Research Involving Human Subjects". Informed consent was obtained from all patients.

\section{Statistical Analysis}

Social Science Statistical Package (SPSS Inc., Chicago, IL, USA) computer software was used for the bio-statistical analysis. When the data were presented as mean values, standard deviation values were given and when it was presented as median values, minimum ( $\min$ )-maximum (max) values were also indicated.

\section{RESULTS}

The age range of our patients who were admitted to our clinic with the diagnosis of acute appendicitis under emergency conditions and who underwent medical or surgical treatment was $25.5 \pm 6.4$ years. No additional disease was present in any of our patients. The duration of hospital admission was between 12-48 hours. The mean gestational week was $18 \pm 9.4$ weeks, three $(17.6 \%)$ patients were in the first trimester, II $(64.8 \%)$ patients were in the second trimester and three (17.6\%) patients were in the third trimester (Table I). All patients were admitted with the complaint of abdominal pain. Of these, 14 $(82.4 \%)$ patients had nausea, five $(29.4 \%)$ patients had vomiting, and four (23.5\%) patients had a loss of appetite.

Abdominal tenderness was observed in all patients on physical examination. Two of the patients with tenderness had defense ( $11.8 \%$ ) and 12 had rebound (70.6\%). No direct radiography and computed tomography (CT) was performed due to pregnancy. Acute appendicitis was not diagnosed in six of our patients on USG examination, which was performed on all patients. The other II patients were diagnosed with acute appendicitis on USG examination, and appendicitis diameter was $7.73 \pm 1.67 \mathrm{~mm}$. Although there were no radiological di-
Table I. The distribution of the patients according to the stage of pregnancy

\begin{tabular}{lcc}
\hline Gestational age & $\mathbf{n}$ & $\%$ \\
\hline I $^{\text {st }}$ trimester & 3 & 17.6 \\
$2^{\text {nd }}$ trimester & 11 & 64.8 \\
$3^{\text {rd }}$ trimester & 3 & 17.6 \\
\hline
\end{tabular}

Table 2. Demographic characteristics of patients $(n=17)$

\begin{tabular}{lccc}
\hline & n & $\%$ & Mean \pm SD \\
\hline Age (years) & & & $25.5 \pm 6.4$ \\
White blood cell count $\left(\times 10^{3} / \mu \mathrm{L}\right)$ & & & $13.06 \pm 3.5$ \\
Hospital stay (day) & & & $2.9 \pm 0.9$ \\
$\quad$ Abdominal pain & 17 & 100 & \\
$\quad$ Nausea & 14 & 82.4 & \\
$\quad$ Vomiting & 5 & 29.4 & \\
$\quad$ Anorexia & 4 & 23.5 & \\
Physical finding & & & \\
$\quad$ Abdominal tenderness & 17 & 100 & \\
$\quad$ Abdominal rebound & 12 & 70.6 & \\
$\quad$ Abdominal defense & 2 & 11.8 & \\
Negative appendectomy & 2 & 13.3 & \\
Treatment approach & & & \\
$\quad$ Medical treatment & 2 & 11.8 & \\
Surgical technique laparoscopic & 3 & 17.6 & \\
Open & 12 & 70.6 & \\
Ultrasonography + & 11 & 64.8 & \\
\hline & & &
\end{tabular}

SD: Standard deviation.

agnoses in three patients, an additional examination was not performed since the anamnesis and physical examination findings were compatible with acute appendicitis. A patient who was in the third trimester was diagnosed with MRI because it had ambiguous examination findings and high leukocyte value. The mean leukocyte count was 13.06 \pm 3.5 . General anesthesia was applied to 15 operated patients.

Two patients were medically followed-up by administering two doses of I g ampicillin sulbactam daily since there was only abdominal pain in the anamnesis, and there were no findings other than tenderness on physical examination. However, there were findings compatible with acute appendicitis on USG examination in these patients and their leukocyte values were less than $10 \mathrm{~K} / \mathrm{uL}$. The patients whose complaints regressed after daily follow-up and who had no positive findings on the examination were discharged with a cure.

Laparoscopic appendectomy was performed in three (17.6\%) of our eligible patients who were at the beginning of the sec- 
ond trimester and whose uterine volume was not expected to prevent laparoscopy. The pressure was maintained below $10 \mathrm{mmHg}$ in carbon dioxide $\left(\mathrm{CO}_{2}\right)$ insufflation during operation. Appendectomy with classical McBurney incision was performed in 10 (58.8\%) patients, and the caesarean section with concurrent appendectomy was performed in two (I I.8\%) patients on the recommendation of the obstetrics and gynecology clinic (Table 2). The mean postoperative hospital stay length of our patients was $2.9 \pm 0.9$ days. There were no complications in both the infants and mothers in the postoperative period. Histopathologically, I 3 (86.7\%) of our operated patients were diagnosed with appendicitis.

\section{DISCUSSION}

Acute appendicitis is a rare condition during pregnancy. It is the most common cause of non-obstetric acute abdomen in pregnancy, although it is seen in one out of 1500-5000 births during pregnancy. ${ }^{[13,14]}$ It is more common in the second trimester of pregnancy. ${ }^{[15]} 64 \%$ of the patients were in the second trimester in our study.

Given that symptoms, such as abdominal pain and nausea, are also present during pregnancy, the abdominal examination is more difficult depending on the progression of the gestational week in the case of pregnancy, patients who present with abdominal pain usually go to gynecologists and obstetricians first, and physicians have reservations due to pregnancy status, only USG examination can be performed and tomography cannot be performed for imaging, organs are located differently from the normal anatomical position due to enlarged uterus makes it difficult to diagnose acute appendicitis in pregnant women. In addition, the clinical condition is confused with other conditions in the differential diagnosis, such as torsional ovarian cyst, acute pyelonephritis, pelvic infection, degenerated uterine myoma, tuba ovarian abscess, fallopian tube torsion, acute cholecystitis, acute pancreatitis, peptic ulcer perforation, intestinal obstruction, preterm labor, ectopic pregnancy and preeclampsia increases perforation and complication rates of acute appendicitis in pregnant women. This may lead to an increase in mortality and morbidity in both mothers and infants. ${ }^{[16-18]}$ The negative appendectomy rate has been reported to be between $3 \%-$ $23 \%$ during pregnancy. ${ }^{[19]}$ This rate was $13.3 \%$ in our study.

Most of our patients are admitted with the complaint of abdominal pain. Apart from that, nausea, vomiting, loss of appetite, fever and, rarely, diarrhea, constipation, and dysuria are other complaints. Although abdominal examination of pregnant appendicitis patients is similar to non-pregnant appendicitis patients in the first trimester, further differences are observed on the examination with the increase of abdominal distention and the displacement of the appendix in the following weeks of gestation. ${ }^{[20]}$ Laboratory tests reveal leukocyte elevation up to $80 \%$ in non-pregnant appendicitis patients, but this rate is physiologically high in three trimes- ters in pregnant women. ${ }^{[20-23]}$ The mean leukocyte value was determined as $13.06 \pm 3.5$ in our patients, and $83 \%$ of the patients had leukocyte elevation, consistent with the literature. Ultrasonography, which is the most commonly used imaging test in pregnant patients, is the used method in the diagnosis of pregnancy appendicitis. The sensitivity and specificity of ultrasonography, which is higher in the first trimester, are lower in the following weeks of gestation compared to the first trimester due to the enlargement of the uterus and the separation of intra-abdominal organs from the normal anatomical position. ${ }^{[5]}$ Acute appendicitis was diagnosed in II of our patients by ultrasonography but could not be evaluated in six patients. The use of tomography in the diagnosis of pregnant patients is negligible due to ionizing radiation.

The use of the laparoscopic method, which has recently been used in pregnant appendicitis patients, in pregnancy appendicitis is more suitable for selected and first trimester patients considering fetal acidosis, preterm labor, decrease in uterine blood supply due to pressure and the damages that may arise during the interventional procedure. ${ }^{[22,23]}$ We chose open the approach in 13 of our patients and performed the surgery. Furthermore, we did not encounter any maternal or fetal mortality. Laparoscopic appendectomy was applied to three patients who were at the beginning of the second trimester. Caesarean section and appendectomy procedures were performed in two patients since they were in the third trimester and close to term, and appendectomy procedure with classical McBurney incision was performed in 10 patients. It was observed that 13 patients had appendicitis and two of them had perforation due to appendicitis necrosis in the pathological examination of the patients who underwent an appendectomy.

The perforation rate in pregnancy appendicitis is higher than normal appendicitis patients due to delay, which increases maternal and fetal mortality and morbidity rates. The overall appendicitis perforation rate has been reported to be $14 \%$ in pregnant patients. ${ }^{[24]}$ Two of our patients were diagnosed with perforated appendicitis. While the mean hospital stay length was 2.96 (2-5) days, the mean duration of hospital stay was five days in patients diagnosed with perforated appendicitis.

\section{Conclusion}

Although appendicitis is rare during pregnancy, it is a disease that requires a multidisciplinary approach with surgery and obstetrics and gynecology clinics in diagnosis and treatment. The multidisciplinary approach becomes even more important since the diagnosis is made later than non-pregnant patients and treatment requires invasive procedures despite pregnancy. It is one of the first conditions that should be kept in mind in patients admitted to obstetrics and gynecology clinics or emergency departments with abdominal pain.

Peer-review: Internally peer-reviewed.

Authorship Contributions: Concept: Y.Y., M.Ş.; Design: 
M.Ş.; Supervision: T.G., M.P.; Resource: Y.Y.; Materials: M.Ş., Y.Y.; Data: T.G., M.P.; Analysis: Y.Y., M.Ş.; Literature search: Y.Y.; Writing: M.Ş., Y.Y.; Critical revision: M.Ş.

\section{Conflict of Interest: None declared.}

Financial Disclosure: The authors declared that this study has received no financial support.

\section{REFERENCES}

1. Zhang Y, Zhao YY, Qiao J, Ye RH. Diagnosis of appendicitis during pregnancy and perinatal outcome in the late pregnancy. Chin Med J (Engl) 2009;122:521-4. [CrossRef]

2. Kapan S, Bozkurt MA, Turhan AN, Gönenç M, Alşs H. Management of acute appendicitis in pregnancy. Ulus Travma Acil Cerrahi Derg 2013;19:20-4. [CrossRef]

3. Jung SJ, Lee DK, Kim JH, Kong PS, Kim KH, Bae SW. Appendicitis during Pregnancy: The Clinical Experience of a Secondary Hospital. J Korean Soc Coloproctol 2012;28:152-9. [CrossRef]

4. Baer JL, Reis RA, Araens RA. Appendicitis in pregnancy with changes in position and axis of the normal appendix in pregnancy. JAMA 1932;98:1359-64. [CrossRef]

5. Lim HK, Bae SH, Seo GS. Diagnosis of acute appendicitis in pregnant women: value of sonography. AJR Am J Roentgenol 1992;159:539-42.

6. Kammere WS. Non-obstetric surgery in pregnancy. Med Clin North Am 1987;71:551-60. [CrossRef]

7. Weingold AB. Appendicitis in pregnancy. Clin Obstet Gynecol 1983;26:801-9. [CrossRef]

8. Babaknia A, Parsa H, Woodruff JD. Appendicitis during pregnancy. Obstet Gynecol 1977;50:40-4.

9. Cunningham FG, McCubbin JH. Appendicitis complicating pregnancy. Obstet Gynecol 1975;45:415-20.

10. Mazze RI, Källén B. Appendectomy during pregnancy: a Swedish registry study of 778 cases. Obstet Gynecol 1991;77:835-40.

11. Tamir IL, Bongard FS, Klein SR. Acute appendicitis in the pregnant pa- tient. Am J Surg 1990;160:571-6. [CrossRef]

12. Basaran A, Basaran M. Diagnosis of acute appendicitis during pregnancy: a systematic review. Obstet Gynecol Surv 2009;64:481-99. [CrossRef]

13. Mourad J, Elliott JP, Erickson L, Lisboa L. Appendicitis in pregnancy: new information that contradicts long-held clinical beliefs. Am J Obstet Gynecol 2000;182:1027-9. [CrossRef]

14. Hée P, Viktrup L. The diagnosis of appendicitis during pregnancy and maternal and fetal outcome after appendectomy. Int J Gynaecol Obstet 1999;65:129-35. [CrossRef]

15. Flexer SM, Tabib N, Peter MB. Suspected appendicitis in pregnancy. Surgeon 2014;12:82-6. [CrossRef]

16. Yağcı MA, Sezer A, Hatipoğlu AR, Coşkun İ, Hoşcoşkun Z. Gebelikte akut apandisit. Dicle Tip Dergisi 2010;37:134-9.

17. Zingone F, Sultan AA, Humes DJ, West J. Risk of acute appendicitis in and around pregnancy: a population-based cohort study from England. Ann Surg 2015;261:332-7. [CrossRef]

18. Epstein FB. Acute abdominal pain in pregnancy. Emerg Med Clin North Am 1994;12:151-65.

19. Arer İM, Alemdaroğlu S, Yeşilağaç H, Yabanoğlu H. Acute appendicitis during pregnancy: case series of 20 pregnant women. Ulus Travma Acil Cerrahi Derg 2016;22:545-8. [CrossRef]

20. Lurie S, Rahamim E, Piper I, Golan A, Sadan O. Total and differential leukocyte counts percentiles in normal pregnancy. Eur J Obstet Gynecol Reprod Biol 2008;136:16-9. [CrossRef]

21. Kuvin SF, Brecher G. Differential neutrophil counts in pregnancy. N Engl J Med 1962;266:877-8. [CrossRef]

22. Danso D, Dimitry ES. Perforated 26 weeks pregnant uterus at appendicectomy. BJOG 2004;111:628-9. [CrossRef]

23. Walsh CA, Walsh SR. Laparoscopic appendectomy during pregnancy: an evidence-based review. Surg Endosc 2009;23:671. [CrossRef]

24. Başkıran A, İnce V, Çiçek E, Şahin T, Dirican A, Balıkçı Çiçek İ, et al. Efficacy of laboratory tests and ultrasonography in the diagnosis of acute appendicitis in gravid patients according to the stages of pregnancy. Ulus Travma Acil Cerrahi Derg 2018;24:333-6. [CrossRef]

\section{ORİJINAL ÇALIŞMA - ÖZET}

\section{Gebelikte akut apandisit}

\section{Dr. Yusuf Yavuz, ${ }^{1}$ Dr. Mustafa Şentürk, ${ }^{2}$ Dr. Tufan Gümüş, ${ }^{1}$ Dr. Mehmet Patmano}

'Şanlıurfa Eğitim ve Araştırma Hastanesi, Genel Cerrahi Kliniği, Şanlıurfa ${ }^{2}$ Necmettin Erbakan Üniversitesi Meram Tıp Fakültesi, Genel Cerrahi Anabilim Dalı, Konya

AMAÇ: Akut apandisit gebelerde non-obstetrik akut karının en sık nedenidir. Bu çalışmada, acil servisimize karın ağrısı nedeniyle başvuran ve akut apandisit tanısı konulan hastalarımızı literatür eşliğinde inceledik.

GEREÇ VE YÖNTEM: 2016-2019 yılları arasında Şanlıurfa Eğitim ve Araştırma Hastanesi Acil Servisine başvuran 17 adet gebe akut apandisit hastası elektronik kayıt ortamında geriye dönük olarak incelendi. Hastalarımız yaş, gebelik haftası, klinik durumları, yapılan operasyon, ultrasonografı sonuçları, patoloji sonuçları, ek hastalık durumları, laboratuvar sonuçları ve yatış süreleri yönünden değerlendirildi.

BULGULAR: Hastalarımızın yaş ortalaması 25.5 (| |8-4I) idi. Başvuru anında 3 hasta birinci trimester (\% | 7.6$)$, I I hasta ikinci trimester (\%64.8), üç hasta da üçüncü trimesterde (\% I7.6) idi. Hastalarımızın hepsinde karın ağııı şikayeti mevcuttu. Yapılan ultrasonografi incelemede II hastada akut apandisit saptanırken altı hastada apandisit izlenemedi. Miadı gelen İki tanesine apendektomi operasyonuyla eş olarak sezeryan işlemi de uygulandı. Hastalarımızın hastanede yatış süresi ortalama 2.9 (2-5) idi. Histopatolojik olarak opere olan hastalarımızın I3'ü (\%86.7) akut apandisit tanısı almış idi. Ameliyat sonrası dönemde anne ve bebeklerde ek problem izlenmedi.

TARTIŞMA: Karın ağrısı ile acil servise başvuran gebe hastalarda akut apandisit non-obstetrik bir patoloji olarak göz önünde tutulmalıdır. Klinik seyir ve fizik muayene bakımından farklılıklar gösteren bu durum titiz ve multidisipliner bir yaklaşımla irdelenmesi anne ve bebek sağlığı açısından önem arz ettiği kanısındayız.

Anahtar sözcükler: Akut apandisit; gebelik; tedavi. 